\title{
Morphology and taxonomy of the Aphanizomenon spp. (Cyanophyceae) and related species in the Nakdong River, South Korea
}

Hui Seong Ryu, Ra Young Shin and Jung Ho Lee*

\begin{abstract}
Background: The purpose of this study is to describe the morphological characteristics of the Aphanizomenon spp. and related species from the natural samples collected in the Nakdong River of South Korea.

Results: Morphological characteristics in the four species classified into the genera Aphanizomenon Morren ex Bornet et Flahault 1888 and Cuspidothrix Rajaniemi et al. 2005 were observed by light microscopy. The following four taxa were identified: Aphanizomenon flos-aquae Ralfs ex Bornet et Flahault, Aphanizomenon klebahnii Elenkin ex Pechar, Aphanizomenon skujae Komárková-Legnerová et Cronberg, and Cuspidothrix issatschenkoi (Usačev) Rajaniemi et al. Aph. flos-aquae and Aph. klebahnii always formed in fascicles; the others only occurred in solitary. Aph. flos-aquae was similar to Aph. klebahnii, whereas these species differed from each other by the size and shape of fascicles, which was macroscopic in Aph. flos-aquae and microscopic in the Aph. klebahnii. One of their characteristics was that trichomes are easily disintegrating during microscopic examination. C. issatschenkoi could be clearly distinguished from other species by hair-shaped terminal cell. Its terminal cell was almost hyaline and markedly pointed. Young populations of the species without heterocytes run a risk of a misidentification. Aph. skujae was characterized by akinete. Morphological variability of akinetes from natural samples collected in the Nakdong River was rather smaller than those reported by previous study.

Conclusions: C. issatschenkoi are described for the first time in the Nakdong River. In addition, Aph. klebahnii and Aph. skujae are new to South Korea.
\end{abstract}

Keywords: Aphanizomenon, Cuspidothrix, Cyanobacteria, Nakdong River, Nostocales

\section{Background}

The genus Aphanizomenon Morren ex Bornet et Flahault 1888 (type species: Aph. flos-aquae) belongs to order Nostocales and family Nostocaceae, which has a worldwide distribution (Rajaniemi et al. 2005a). The species of genus Aphanizomenon and several of its members have been described as the cause for harmful bloom (Mcdonald and Lehman 2013; Ma et al. 2015). Some species can produce hepatotoxic and neurotoxic, such as aphantoxin, anatoxin-a, cylindrospermopsin, and saxitoxin, cyanobacterial secondary metabolites which can cause critical

\footnotetext{
* Correspondence: jungho@daegu.ac.kr

Department of Biology Education, Daegu University, Gyeongbuk 38453, South Korea
}

(c) The Author(s). 2017 Open Access This article is distributed under the terms of the Creative Commons Attribution 4.0 International License (http://creativecommons.org/licenses/by/4.0/), which permits unrestricted use, distribution, and reproduction in any medium, provided you give appropriate credit to the original author(s) and the source, provide a link to the Creative Commons license, and indicate if changes were made. The Creative Commons Public Domain Dedication waiver (http://creativecommons.org/publicdomain/zero/1.0/) applies to the data made available in this article, unless otherwise stated.
Zhang et al. 2015). Therefore, it is very important for the accurate species identification of Aphanizomenon because of water bloom with several toxin-producing species (Guzmán-Guillén et al. 2015).

In the Nakdong River, Microcystis and Anabaena have been considered as the representative bloom-forming cyanobacteria genera (Yu et al. 2014). After the construction of eight weirs, the number of its bloom has been recently growing in mid-upperstream (Ryu et al. 2016). Nevertheless, two Aphanizomenon floras (Aph. flos-aquae and Aph. issatschenkoi) have been described until a recent date (Park 2004) in South Korea; only one Aphanizomenon species has been reported in the ecological study of 


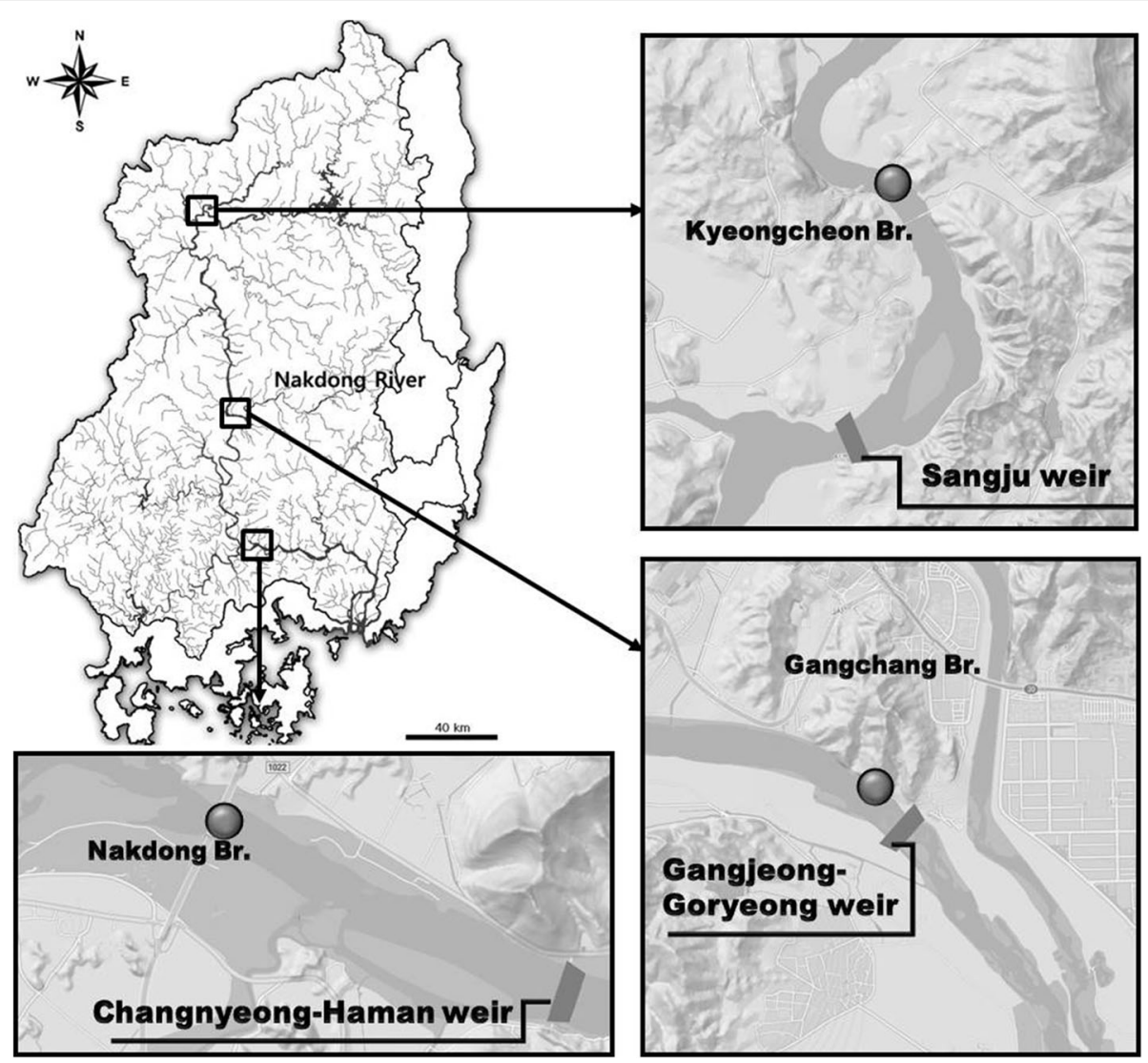

Fig. 1 Map showing the sampling stations (marked as closed circles) in the Nakdong River

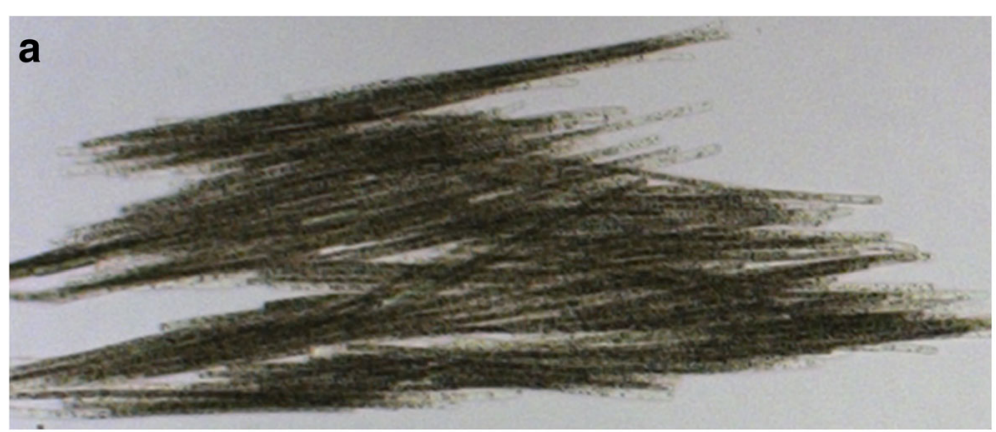

b

C

d

Fig. 2 Photographs of genus Aphanizomenon from natural samples collected in the Nakdong River. a Aph. flos-aquae. b Aph. klebahnii. c Aph. skujae. d Cuspidothrix issatschenkoi 
Nakdong River: Aph. flos-aquae (Choi et al. 2007; Yu et al. 2014). Recent studies using polyphasic approach, e.g., involving morphology but also ecology and phylogenetics, have revealed that the genus Apohanizomenon is in reality very heterogeneous (Cirés and Ballot 2016). According to newly defined approach, 22 taxa identified and described throughout the world have been assigned to the new genera Aphanizomenon (e.g., Aph. flos-aquae Ralfs ex Bornet et Flahault), Cuspidothrix (e.g., former Aph. issatschenkoi (Usačev) Proshkina-Lavrenko), Sphaerospermopsis (e.g., former Aphanizomenon aphanizomenoides
(Forti) Hortobágyi and Komárek), Chrysosporum (e.g., former Aphanizomenon ovalisporum Forti), Anabaenal Aphanizomenon like (e.g., Aphanizomenon gracile (Lemmermann) Lemmermann), and Anabaena-like group (e.g., Aphanizomenon volzii (Lemmermann) Komárek) (Lyra et al. 2001; Gugger et al. 2002; Rajaniemi et al. 2005b; Komárek and Komárková 2006; Zapomělová et al. 2012; Komárek 2013).

The classification of genus Aphanizomenon which frequently form blooms is in some cases difficult that is due to lack of the study for morphology and taxonomy
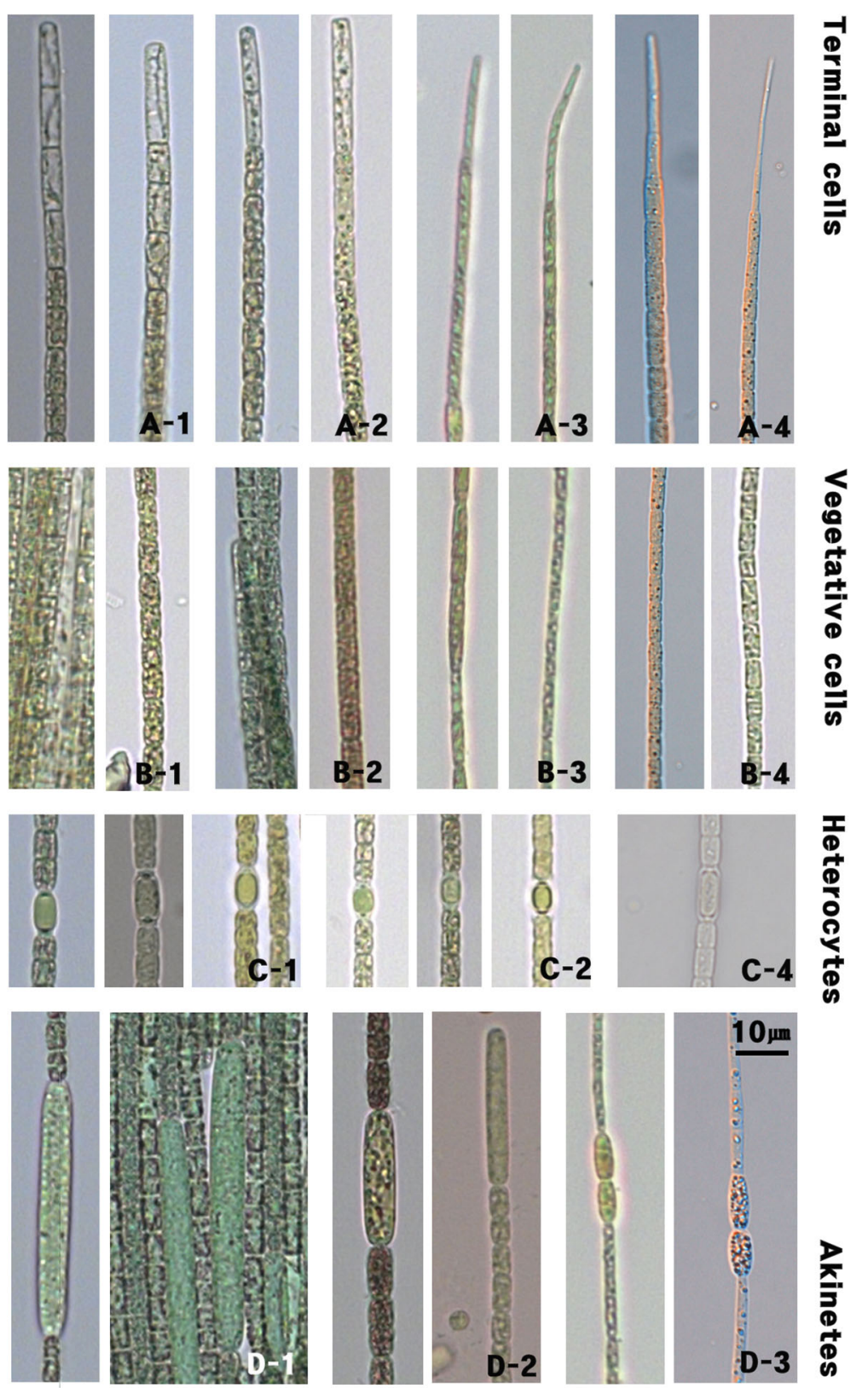

Fig. 3 Terminal cells, vegetative cells, heterocytes, and akinetes of the four Aphanizomenon taxa from natural samples collected in the Nakdong River. A-1, B-1, C-1, D-1 Aph. flos-aquae. A-2, B-2, C-2, D-2 Aph. klebahnii. A-3, B-3, D-3 Aph. skujae. A-4, B-4, C-4 Cuspidothrix issatschenkoi 
in South Korea. The purpose of this study is to describe the morphological characteristics of the Aphanizomenon spp. and related species from the natural samples collected in the Nakdong River, South Korea.

\section{Methods}

The cyanobacteria samples were collected on three stations of the Nakdong River where the stations located in Sangju

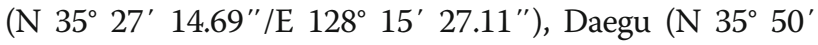
$35.58^{\prime \prime} / \mathrm{E} 128^{\circ} 27^{\prime} 33.92^{\prime \prime}$ ), and Haman (N 35 23' 40.89"/ E $\left.128^{\circ} 31^{\prime} 11.84^{\prime \prime}\right)$, respectively (Fig. 1). The samples were collected from June 2015 to May 2016 with 1-month interval using the plankton net (mesh size $32 \mu \mathrm{m}$ ). It was preserved in $4 \%$ Lugol's solution or formaldehyde water and was transferred at the laboratory. The morphology of trichomes, vegetative cells, heterocytes, and akinetes were studied using Nikon ECLIPSE 80i light microscope with a digital camera. NIS-Elements F 3.0 software was used for image analysis. The following parameters were selected to describe the morphology of the studied specimens: length and width of vegetative cell, heterocytes, and akinetes; morphology of terminal cell; distance between heterocytes and distance between a heterocyte and the nearest akinete (counted as the number of cells); presence or absence of terminal heterocytes and gas vesicles; and shape of trichomes and its aggregation in colonies. All measurements were obtained with the preserved materials.

\section{Results and discussion}

Within the genus Aphanizomenon, three clusters were distinguished by Komárek and Komárková (2006) and
Komárek (2013) for classification. The first cluster (i) included the type species Aph. flos-aquae Ralfs ex Bornet et Flahault 1888 and Aphanizomenon klebahnii Elenkin ex Pechar 2008, together with Aph. yezoense, Aph. paraflexuosum, Aph. flexuosum, Aph. solvenicum, Aph. platense, and Aph. hungaricum. Trichomes of Aph. flos-aquae and Aph. klebahnii taxa always formed macroscopic and microscopic fascicles, and those were able to cause intensive water blooms in eutrophic stagnant water (Hindák 2000). Aph. flos-aquae was common species with Microcystis spp. and Anabeana spp. and the major component of the water bloom in the Nakdong River (Park et al. 2015; Yu et al. 2014). Whereas Aph. klebahnii was described for the first time in the South Korea. Cluster (ii) included species with slightly curved or flexuous trichomes. The terminal cells were narrowed, elongated, and hyaline with sharply pointed. Akinetes were distant to heterocytes. This cluster included Cuspidothrix issatschenkoi (Usačev) Rajaniemi et al. 2005, together with C. elenkinii, Aph. tropicalis, Aph. capricorni, and Aph. ussatchevii. C. issatschenkoi was described for the first time in the Nakdong River. Cluster (iii) was comprised of species described as morphotype of Aphanizomenon gracile with straight, solitary trichomes and with narrowed ends, which belong into the vicinity of Dolichospermum according to molecular sequences. Aph. skujae Komárková-Legnerová et Cronberg 1992 belonged to this cluster, together with Aph. gracile, Aph. Schindleri, Aph. manguinii, Aph. chinense, and Aph. sphaericum. Identification of the species is the first report in South Korea.

Table 1 Diacritical morphological characteristics of four Aphanizomenon taxa reviewed from natural samples collected in the Nakdong River

\begin{tabular}{|c|c|c|c|c|c|}
\hline Species & Fascicles trichomes & Terminal cells & Vegetative cells & Heterocytes & Akinetes \\
\hline $\begin{array}{l}\text { Aphanizomenon } \\
\text { flos-aquae }\end{array}$ & $\begin{array}{l}\text { Band-like, up to } 2 \mathrm{~cm} \\
\text { long, straight or bent, } \\
\text { often grouped in } \\
\text { fascicles }\end{array}$ & $\begin{array}{l}\text { Elongated cylindrical, } \\
\text { not narrowed, without } \\
\text { aerotopes, almost hyaline }\end{array}$ & $\begin{array}{l}\text { Cylindrical to slightly } \\
\text { barrel-shaped, } 4.0-12.1 \\
\times 3.6-5.6 \mu^{a}(n=45)\end{array}$ & $\begin{array}{l}\text { Intercalary, solitary, } \\
\text { cylindrical, 6.6-8.5 } \\
\times 3.3-3.9 \mu \mathrm{m}^{\mathrm{a}}(n=19)\end{array}$ & $\begin{array}{l}\text { Intercalary, long cylindrical, } \\
\text { distant from heterocytes, } \\
30-62 \times 5.2-7.5 \mu^{\mathrm{a}}(n=22)\end{array}$ \\
\hline $\begin{array}{l}\text { Aphanizomenon } \\
\text { klebahnii }\end{array}$ & $\begin{array}{l}\text { Spindle-like, up to } \\
3 \text { mm long, straight } \\
\text { or slightly arcuated, } \\
\text { often grouped in } \\
\text { fascicles }\end{array}$ & $\begin{array}{l}\text { Elongated cylindrical, } \\
\text { without aerotopes, and } \\
\text { with remaining cytoplasm } \\
\text { in the form of fine granulation }\end{array}$ & $\begin{array}{l}\text { Cylindrical or slightly } \\
\text { barrel-shaped, 3.9-8.3 } \\
\times 3.6-4.9 \mu^{\mathrm{a}}(n=31)\end{array}$ & $\begin{array}{l}\text { Solitary, intercalary, } \\
\text { oval to cylindrical, } \\
5.5-6.7 \times 3.2-4.0 \mu^{\mathrm{a}} \\
(n=6)\end{array}$ & $\begin{array}{l}\text { Intercalary, solitary, } \\
\text { elongated cylindrical, } \\
26-39 \times 4.5-5.9 \mu^{a}(n=17)\end{array}$ \\
\hline $\begin{array}{l}\text { Aphanizomenon } \\
\text { skujae }\end{array}$ & $\begin{array}{l}\text { Solitary, straight, bent } \\
\text { or irregularly curved }\end{array}$ & $\begin{array}{l}\text { Narrowed and elongated, } \\
\text { bluntly pointed, containing } \\
\text { a smaller amount of pigment } \\
\text { and sporadic aerotopes }\end{array}$ & $\begin{array}{l}4.8-8.4 \times 1.2-2.5 \mu \mathrm{m}^{\mathrm{a}} \\
(n=19)\end{array}$ & $\begin{array}{l}\text { Solitary, intercalary, } \\
\text { oval to cylindrical, } \\
6-15 \times 2-3 \mu^{b}\end{array}$ & $\begin{array}{l}\text { Solitary or up to } 3 \text { in a row, } \\
\text { cylindrical with rounded } \\
\text { ends, wider than trichomes, } \\
7.6-11.8 \times 3.8-4.6 \mu^{a} \\
(n=13)\end{array}$ \\
\hline $\begin{array}{l}\text { Cuspidothrix } \\
\text { issatschenkoi }\end{array}$ & $\begin{array}{l}\text { Solitary, straight, } \\
\text { bent, or slightly } \\
\text { coiled }\end{array}$ & $\begin{array}{l}\text { Tapered like hair-shaped, } \\
\text { almost hyaline, continually } \\
\text { pointed }\end{array}$ & $\begin{array}{l}\text { Cylindrical to long- } \\
\text { cylindrical, usually } \\
\text { with scarce aerotopes, } \\
4.4-7.0 \times 2.5-3.3 \mu \mathrm{m}^{\mathrm{a}} \\
(n=36)\end{array}$ & $\begin{array}{l}\text { Solitary, intercalary, } \\
6.6-8.7 \times 3.4-3.7 \mathrm{\mu m}^{\mathrm{a}} \\
(n=5)\end{array}$ & $\begin{array}{l}\text { Solitary or 2-3 in a row, } \\
\text { distant from heterocytes, } \\
\text { long cylindrical with } \\
\text { rounded ends, } 8.5-12.5 \\
\times 4-4.6 \mathrm{~m}^{c}\end{array}$ \\
\hline
\end{tabular}

$n$ number of identified samples

a This study

bKomárek 2013

${ }^{\text {c } R a j a n i e m i ~ e t ~ a l . ~ 2005 b ~}$ 
The four investigated species in the Nakdong River were classified in the genus Aphanizomenon (Aph. flos-aquae, Aph. klebahnii, Aph. skujae) and in the genus Cuspidothrix (C. issatschenkoi). Morphological characteristic of trichomes, heterocytes, and akinetes from natural samples collected in the Nakdong River is shown in Figs. 2 and 3 and Table 1 and that investigated from studies cited is shown in Fig. 4.

\section{Systematics of genus Aphanizomenon and genus}

Cuspidothrix

Class Cyanophyceae Sachs 1874

Order Nostocales Borzi 1914

Family Nostocaceae C.A. Agardh 1824 ex Korchner 1898

Genus Aphanizomenon Morren ex Bornet et Flahault 1888
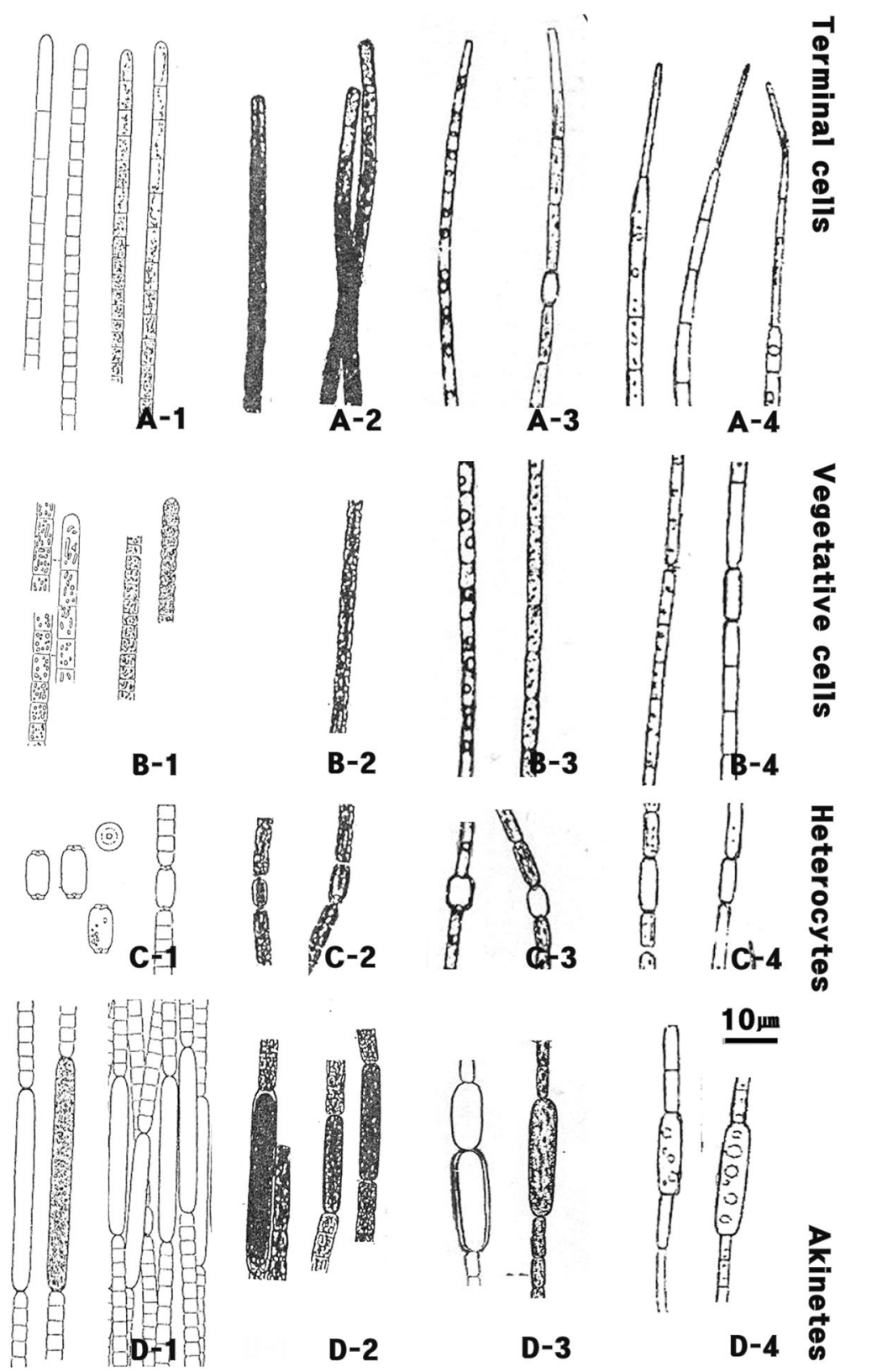

Fig. 4 Terminal cells, vegetative cells, heterocytes, and akinetes of the four Aphanizomenon taxa investigated from studies cited. A-1, B-1, C-1, D-1 Aph. flos-aquae - after Komárek (1958). A-2, B-2, C-2, D-2 Aph. klebahnii-after Komárek et Kováčik (1989). A-3, B-3, D-3 Aph. skujae—after Skuja (1956) and Komárková-Legnerová et Cronberg (1992). A-4, B-4, C-4 Cuspidothrix issatschenkoi-after Usačev from Kondraeva 1968 and after Hindák et Moustaka (1988) 
Aphanizomenon flos-aquae Ralfs ex Bornet et Flahault 1888

Aphanizomenon klebahnii Elenkin ex Pechar 2008

Aphanizomenon skujae Komárková-Legnerová et Cronberg 1992

Genus Cuspidothrix Rajaniemi et al. 2005

Cuspidothrix issatschenkoi (Usačev) Rajaniemi et al. 2005

\section{Morphology and taxonomy of individual species}

Aphanizomenon flos-aquae Ralf ex Bornet et Flahault (Fig. 2a; Fig. 3A-1 D-1)

(Smith 1950, p. 585, fig. 503; Hirose et al. 1977, p. 85, pl. 36 3a-3d; Komárek and Kováčik 1989, fig. 8; John et al. 2002, p. 96, pl. 18g-j; Rajanieimi et al. 2005b, Fig. 7. a; Komárek and Komárková 2006, Fig. 6; Komárek 2013, p. 688, Fig. 853)

Synonyms: Aphanizomenon incurvum Morren 1835; Aphnizomenon cyaneum Ralfs 1850; Aphanizomenon holsaticum Richter 1896; Aphanizomenon americanum Reinhard 1941

This species was common in Asian freshwater not only in South Korea (Park et al. 2015; Ryu et al. 2016) but also in China (Wu et al. 2010; Ma et al. 2015) and in Japan (Takano and Hino 2009; Yamamoto 2009). Studied samples were collected from all stations. The species was characterized by a tendency to aggregate trichomes in parallel fascicles which can reach a macroscopic size of up to $2 \mathrm{~cm}$. Trichomes of the species were straight or bent, cylindrical, and slightly constricted at the cross-walls. Other morphological features include an isopolar and at the ends cylindrical-rounded (Fig. 2a). Trichomes were easily disintegrating by shaking or fixing solution during microscopic examination (Fig. 5). Cells were cylindrica to slightly barrel-shaped, isodiametric with olive-green protoplast and numerous aerotopes, 4-12.1 ×3.6-5.6 $\mu \mathrm{m}$; terminal cells elongated and up to 19.1 long, without aerotope, almost hyline, usually with characteristic remains of cytoplasm in form of an irregular (Fig. 3A-1). Heterocytes were intercalary, solitary (up to 3 ) in a trichome, cylindrical, and 6.6-8.5 × 5-8.5 $\mu \mathrm{m}$. Morphological variability of akinetes from natural samples collected in the Nakdong River was rather smaller. Akinetes were reported by Komárek (2013) as $40-220 \times 6-10.8 \mu \mathrm{m}$, however mostly 30-62 ×5.2-7.5 $\mu \mathrm{m}$, intercalary, long cylindrical, and distant from heterocyte (Table 1).

Ecology: This species is planktonic in eutrophic reservoir (Komárek 2013). It has shown positive growth within a wide range of temperatures $\left(16-25{ }^{\circ} \mathrm{C}\right)$ (Preussel et al. 2009) and can grow below $10{ }^{\circ} \mathrm{C}$ (Üveges et al. 2012). It has a competitive advantage under situations of low light intensities (Mehnert et al. 2010). We collected this specimen in waterbodies of mesotrophic or eutrophic status (range of total phosphorus $0.017-0.040 \mathrm{mg} \mathrm{L}^{-1}$ ).
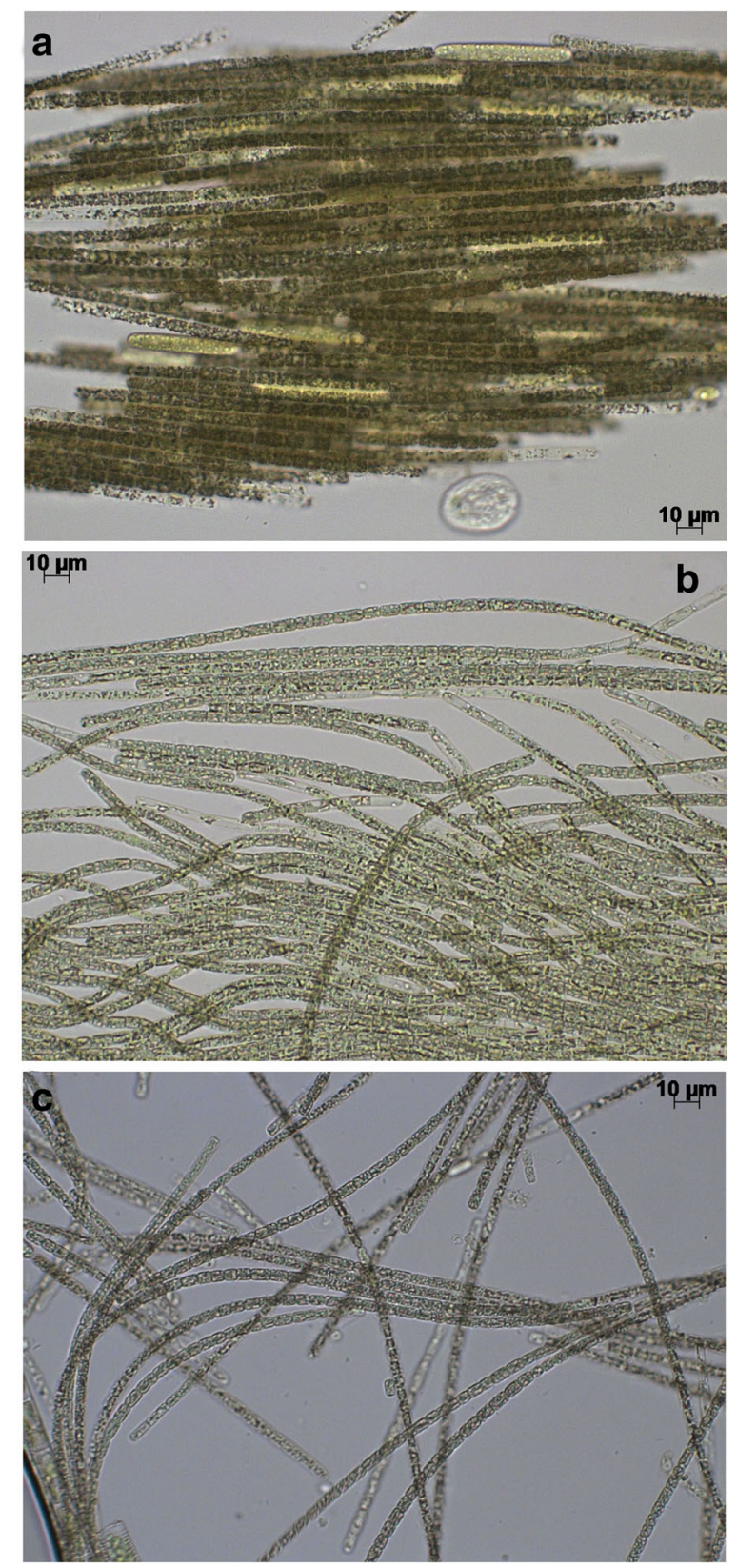

Fig. 5 Serial photos of easily disintegrating characteristics of Aphanizomenon flos-aquae from natural samples collected in the Nakdong River. a Trichomes were grouped in fascicles on sampling day (no shaking, no fixing). b Trichomes were disintergrated by shaking on sampling day (no fixing). c Trichome were disintergrated by fixing solution and shaking after 3 days

Material examined: Sangju (Jun. 2015, Oct. 2015, Dec. 2015, Nov. 2015, Jan. 2015, May. 2016), Daegu (Jun. 2015, Oct. 2015, Dec. 2015, Nov. 2015, Jan. 2016, Feb. 2016, Mar. 2016, Apr. 2016, May 2016), Haman (Jun. 2015, Oct. 2015, Dec. 2015, Nov. 2015, Jan. 2016, Feb. 2016, Mar. 2016, Apr. 2016, May 2016) 
Aphanizomenon klebahnii Elenkin ex Pechar (Fig. 2b; Fig. 3A-2 D-2)

(Hirose et al. 1977, p. 85, pl. 36 4a-4b; Komárek and Kováčik 1989, fig. 9; Komárek 2013, p. 690, Fig. 855)

Synonyms: Aphanizomenon flos-aquae var. klebahnii Elenkin 1909; Aphnizomenon klebahnii Elenkin 1909 (Nomen alternat.)

Blooms of this species have been frequently observed in the Japanese lakes (Yamamoto 2009); however, the species has not been recorded in South Korea. Single free-floating trichomes of the species were aggregated in parallel in spindle-like fascicles and up to $2 \mathrm{~mm}$ long. Trichomes were straight or slightly arcuated cylindrical; almost not or only very slightly constricted at the crosswalls; isopolar, on both ends with elongated cylindrical; and not narrowed cells (Fig. 2b). Cells were cylindrical or slightly barrel-shaped, isodiametric, with olive-green protoplast with numerous aerotopes, and 3.9-8.3 × 3.6$4.9 \mu \mathrm{m}$; terminal cells were elongated, up to $12 \mu \mathrm{m}$ long, without aerotopes, and with remaining cytoplasm in the form of fine granulation (Fig. 3A-2). Heterocytes were solitary, intercalary, 1-2 in the trichome, oval to cylindrical, and 5.5-6.7 × 3.2-4.0 $\mu \mathrm{m}$. Akinetes were developed asymmetrically on the trichome, intercalary, solitary or rarely in pairs, elongated cylindrical, and $26-39 \times 4.5-$ $5.9 \mu \mathrm{m}$ (Table 1). This species was very similar to the species, Aph. flos-aquae Ralfs ex Bornet et Flahault, namely in shape, size, and color of cells, terminal cell, and heterocytes. However, this species differed from Aph. flosaquae only by the size and shape of fascicles, which is macroscopic in Aph. flos-aquae and microscopic in Aph. klebahnii (Fig. 6, Table 1).

Ecology: This species is planktonic in eutrophic up to hypertrophic reservoir (Komárek 2013). It is adapted to high water temperatures (Yamamoto and Nakahara 2006). We collected this specimen in waterbodies of mesotrophic or eutrophic status (range of total phosphorus $\left.0.028-0.036 \mathrm{mg} \mathrm{L}^{-1}\right)$.
Material examined: Daegu (Oct. 2015, Nov. 2015), Haman (Oct. 2015, Feb. 2016)

Aphanizomenon skujae Komárková-Legnerová et Cronberg (Fig. 2c; Fig. 3A-3, B-3, D-3)

(Komárek and Komárková 2006, Fig. 17)

Synonyms: Aphanizomenon cf. flos-aquae var. klebahnii sensu Skuja 1956

Identification of this species is the first report in South Korea. Trichomes of the species were solitary, fine, straight, bent or irregularly curved, and without mucilage (Fig. 2c). Cells usually were with aerotopes, particularly in the central part, towards the ends sometimes more hyaline, $4.8-8.4 \times 1.2-2.5 \mu \mathrm{m}$; terminal cells were narrow and elongated, containing a smaller amount of pigment and sporadic aerotopes. Terminal cells were bluntly pointed (Fig. 3A-3). Heterocytes were not found from natural samples collected in the Nakdong River. Akinetes were oval to cylindrical with rounded ends, conspicuously wider than vegetative cells, and with an akinete/trichome width ratio often greater than twofold. Morphological variability of akinetes from natural samples collected in the Nakdong River was rather small. It was reported by Komárek (2013) as $20-34 \times 2.7-4.7 \mu \mathrm{m}$ but mostly $7.6-11.8 \times 3.8-4.6 \mu \mathrm{m}$. Akinetes range from 1 to 2 in number (rarely up to 3 ) in a row, with smooth and colorless exospore; the content was greenish and granular (Table 1).

Ecology: This species is planktonic in lakes. It is distributed in northern and colder parts of temperate zone in Eurasia (Komárek 2013). We collected this specimen in waterbodies of oligotrophic status (total phosphorus $0.009 \mathrm{mg} \mathrm{L}^{-1}$ ).

Material examined: Sangju (Jun. 2015)

Cuspidothrix issatschenkoi (Usačev) Rajaniemi et al. 2005 (Fig. 2d; Fig. 3A-4 C-4)

(John et al. 2002, p. 96, pl. 18k; Rajanieimi et al. 2005b, Fig. 7. c; Komárek and Komárková 2006, Fig. 31; Figueiredo et al. 2011, Fig. 1. a-c; Ballot et al. 2010. Fig. 1; Komárek 2013, p. 668, Figs. 822-823)

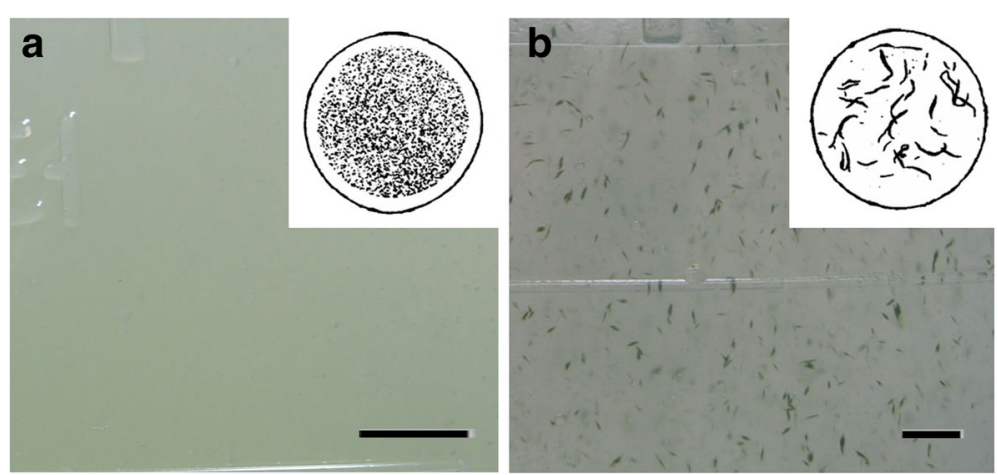

Fig. 6 Comparison of size and shape of fascicles from natural samples collected in the Nakdong River. a Aphanizomenon klebahnii (microscopic size) and $\mathbf{b}$ Aphanizomenon flos-aquae (macroscopic size). Scale bar is $10 \mathrm{~mm}$. Shape of fascicles in circles was depicted by Pechar and Kalina from Komárek and Komárková (2006) 
Synonyms: Aphanizomenon issatschenkoi Usačev 1938

The presence of this species has been reported in freshwaters from many European countries (Kastovsky et al. 2010) and in Asia including China (Wu et al. 2010; Ballot et al. 2010), Japan (Watanabe 1985), and Singapore (Pham et al. 2011). In South Korea, this species has been described only one time until a recent date in the Han River (Park 2004) and it is described for the first time in the Nakdong River. The species was characterized by solitary, bent, or slightly coiled trichomes. The trichomes were isopolar, cylindrical in central part, and continually narrowed or pointed towards ends (developed trichomes). Other morphological features include a not or slightly constricted at the cross-walls and subsymmetric (Fig. 2d). Cells were cylindrical to long cylindrical, usually with scarce aerotopes, $4.4-7.0 \times 2.5-3.3 \mu \mathrm{m}$; terminal cell was almost hyaline and markedly pointed. The hair-shaped terminal cell was in general narrower than the vegetative cells and continually elongated (Fig. 3A-4). Heterocytes were solitary, intercalary, 1-2 (rarely 3 ) on a trichome, cylindrical, and 6.6-8.7 ×3.4-3.7 $\mu \mathrm{m}$. Akinetes were not found from natural samples collected in the Nakdong River. This species was easily recognized by trichomes with hair-shaped terminal cells. However, young field populations of this species without heterocytes can be easily misidentified as the very similar Rapidiopsis mediterranea Skuja or as the non-heterocystous life stages of Cylindrospermopsis raciborskii (Woloszynska) Seenayya and Subba Raju (Moustaka-Gouni et al. 2010).

Ecology: This species is sporadically planktonic in mesotrophic and eutrophic reservoirs (Komárek 2013). It has shown positive growth within a moderate range of temperatures $\left(22-28{ }^{\circ} \mathrm{C}\right.$ ) (Dias et al. 2002). It has also been observed thriving in freshwater, as well as in oligohaline and brackish waters (Marshall et al. 2005). We collected this specimen in waterbodies of eutrophic status (range of total phosphorus $0.032-0.043 \mathrm{mg} \mathrm{L}^{-1}$ ).

Material examined: Haman (Oct. 2015, Nov. 2015, Apr. 2016)

\section{Conclusions}

The four investigated species in the Nakdong River were classified in the genus Aphanizomenon (Aph. flos-aquae, Aph. klebahnii, Aph. skujae) and in the genus Cuspidothrix (C. issatschenkoi). C. issatschenkoi are described for the first time in the Nakdong River. In addition, Aph. klebahnii and Aph. skujae are new to South Korea.

\section{Acknowledgements}

Not applicable.

Funding

This research was supported by the Daegu University Research Grant 2013.

Availability of data and materials

Please contact author for data requests.

\section{Authors' contributions}

RHS carried out the design of the study, performed the fieldwork, and drafted the manuscript. SRY participated in the microscopic analysis. LJH participated in the design and coordination of manuscript and helped draft the manuscript. All authors read and approved the final manuscript.

\section{Competing interests}

The authors declare that they have no competing interests.

\section{Consent for publication}

Not applicable.

Ethics approval and consent to participate

Not applicable.

Received: 22 September 2016 Accepted: 6 December 2016

Published online: 24 December 2016

\section{References}

Ballot, A., Fastner, J., Lentz, M., \& Wiedner, C. (2010). First report of anatoxin-aproducing cyanobacterium Aphanizomenon issatschenkoi in northeastern Germany. Toxicon, 56, 964-971.

Choi, C. M., Kim, J. H., Lee, J. S., Jung, G. B., Lee, J. T., \& Moon, S. G. (2007). Phytoplankton flora and community structure in the lower Nakdong River. Korean Journal of Environmental Agriculture, 26(2), 159-170.

Cirés, S., \& Ballot, A. (2016). A review of the phylogeny, ecology and toxin production of bloom-forming Aphanizomenon spp. and related species within the Nostocales (cyanobacteria). Harmful Algae, 54, 21-43.

Dias, E., Pereira, P., \& Franca, S. (2002). Production of paralytic shellfish toxins by Aphanizomenon sp. LMECYA 31 (cyanobacteria). Journal of Phycology, 38(4), 705-712

Figueiredo, D. R., Ana, M. M., Gonçalves, B. B., Castro, F., Gonçalves, M., Pereira, J., \& Correia, A. (2011). Differential inter- and intra-specific responses of Aphanizomenon strains to nutrient limitation and algal growth inhibition. Journalof Plankton Research, 33, 1606-1616.

Gugger, M., Lyra, C., Henriksen, P., Coute, A., Humbert, J. F., \& Sivonen, K. (2002). Phylogenetic comparison of the cyanobacterial genera Anabaena and Aphanzomenon. International Journal of Systematic and Evolutionary Microbiology, 52, 1867-1880.

Guzmán-Guillén, R., Manzano, I. L., Moreno, I. M., Ortega, A. I. P., Moyano, R., Blanco, A., \& Cameán, A. M. (2015). Cylindrospermopsin induces neurotoxicity in tilapia fish (Oreochromis niloticus) exposed to Aphanizomenon ovalisporum. Aquatic Toxicology, 161, 17-24.

Hindák, F. (2000). Morphological variation of four planktic nostocalean cyanophytes-members of the genus Aphanizomenon or Anabaena? Hydrobiologia, 438, 107-116.

Hindák, F., \& Moustaka, M. T. (1988). Planktic cyanophytes of Lake Volvi, Greece. Archiv für Hydrobiologie/Algological Studies, 50-53, 497-528.

Hirose, H. M., Akiyama, T., Imahori, H., Kasaki, H., Juamo, S., Kobayasi, H., Takahashi, E., Tsumura, T., Hirano, M., \& Yamagishi, T. (1977). Illustrations of the Japanese freshwater algae (p. 933 pp). Tokyo: Uchidarokakugo Publishing Co., Ltd.

John D.M., Whitton B.A. and Brook A.J. 2002. The freshwater algal flora of the British isles: An identification guide to freshwater and terrestrial algae. Cambridge University Press, 702 pp.

Kastovsky, J., Hauer, T., Mares, J., Krautova, M., Besta, T., Komarek, J., Desortova, B., Hetesa, J., Hindakova, A., Houk, V., Janecek, E., Kopp, R., Marvan, P., Pumann, P. , Skacelova, O., \& Zapomĕlová, E. (2010). A review of the alien and expansive species of freshwater cyanobacteria and algae in the Czech Republic. Biological Invasions, 12(10), 3599-3625.

Komárek, J. (1958). Die taxonomische revision der planktishen blaualgen der Tschechoslowakei. In Algologische Studien, P. 10-206, Academia, Praha.

Komárek, J. (2013). Cyanoprokaryota 3. Teil/3rd part: Heterocytous Genera. In B. Bübel, G. Gärtner, L. Krienitz, \& M. Schagerl (Eds.), SüBwasserflora von Mutteleuropa, 19/3. Springer Spektrum (p. 1131 pp).

Komárek, J., \& Komárková, J. (2006). Diversity of Aphanizomenon-like Cyanobacteria. Czech Phycology, Olomouc, 6, 1-32.

Komárek, J., \& Kováčik, L. (1989). Trichome structure of four Aphanizomenon taxa (Cyanophyceae) from Czechoslovakia, with notes on the taxonomy and delimitation of the genus. Plant Systematics and Evolution, 164, 47-64. 
Komárková-Lengnerová, J., \& Cronberg, G. (1992). New and recombined filamentous cyanophytes from lakes in South Scania, Sweden. Archiv für Hydrobiologie/Algological Studies, 67, 21-37.

Kondrateva, N. V. (1968). Sin'o-zeleni vodorosti-Cyanophyta.-[Blue-green algaeCyanophyta.]. In Viznač. Prosnov. Vodorost. Ukr. RSR 1(2): 1-524, Vidav. "Naukova Dumka", Kiev.

Lyra, C., Soumalainen, S., Gugger, M., Vezie, C., Sundman, P., Paulin, L., \& Sivonen, K. (2001). Molecular characterization of planktic cyanobacteria of Anabaena, Aphanizomenon, Microcystis and Planktothrix genera. International Journal of Systematic and Evolutionary Microbiology, 51, 513-526.

Ma, H., Wu, Y., Gan, N., Zheng, L., Li, T., \& Song, L. (2015). Growth inhibitory effect of Microcystis on Aphanizomenon flos-aquae isolated from cyanobacteria bloom in Lake Dianchi. Harmful Algae, 42, 43-51.

Marshall, H. G., Burchardt, L., \& Lacouture, R. (2005). A review of phytoplankton composition within Chesapeake Bay and its tidal estuaries. Journal of Plankton Research, 27(11), 1083-1102.

McDonald, K. E., \& Lehman, J. T. (2013). Dynamics of Aphanizomenon and Microcystis (cyanobacteria) during experimental manipulation of an urban impoundment. Lake and Reservoir Management, 29(2), 272-276.

Mehnert, G., Leunert, F., Cirés, S., Jöhnk, K. D., Rücker, J., Nixdorf, B., \& Wiedner, C. (2010). Competitiveness of invasive and native cyanobacteria from temperate freshwaters under various light and temperature conditions. Journal of Plankton Research, 32(7), 1009-1021.

Moustaka-Gouni, M., Kormas, K. A., Polykarpou, P., Gkelis, S., Bobori, D. C., \& Vardaka, E. (2010). Polyphasic evaluation of Aphanizomenon issatschenkoi and Raphidiopsis mediterranea in a Mediterranean lake. Journal of Plankton Research, 32(6), 927-936.

Paerl, H. W., \& Huisman, J. (2009). Climate change: a catalyst for global expansion of harmful cyanobacterial blooms. Environmental Microbiology Reports, 1(1), 27-37.

Park, H. K. (2004). Phytoplankton of Lake Paldang, Han River Environment Research Center (p. 131 pp).

Park, H. K., Shin, R. Y., Lee, H. J., Lee, K. L., \& Cheon, S. U. (2015). Spatio-temporal characteristics of cyanobacterial communities in the middle-downstream of Nakdong River and Lake Dukdong. Journal of Korean Society on Water Environment, 31(3), 286-294.

Pharm, M. N., Onodera, H., Andrinolo, D., Franca, S., Araujo, F., Lagos, N., \& Oshima, Y. (2011). A checklist of the algae of Singapore. Singpore: Raffles Museum of Biodiversity Research (pp. 1-100). Singapore: National University of Singapore.

Preussel, K., Wessel, G., Fastner, J., \& Chorus, I. (2009). Responde of cylindrospermopsin production and release in Aphanizomenon flos-aquae (Cyanobacteria) to varying light and temperature conditions. Harmful Algae, 8(5), 645-650

Rajaniemi, P., Hrouzek, P., Kaštovska, K., Willame, R., Rantala, A., Hoffmann, L., Komárek, J., \& Sivonen, K. (2005). Phylogenetic and morphological evaluation of the genera Anabaena, Aphanizomenon, Trichormus and Nostoc (Nostocales, Cyanobacteria). International Journal of Systematic and Evolutionary Microbiology, 55, 11-26

Rajaniemi, P., Komárek, J., Willame, R., Hrouzek, P. Kaštovska, K., Hoffmann, L., \& Sivonen, K. (2005). Taxonomic consequences from the combined molecular and phenotype evaluation of selected Anabaena and Aphanizomenon strains. Algologicals Studies, 117, 371-391.

Ryu, H. S., Park, H. K., Lee, H. J., Shin, R. Y., \& Cheon, S. U. (2016). Occurrence and succession pattern of cyanobacteria in the upper region of the Nakdong River: factors influencing Aphanizomenon bloom. Journal of Korean Society on Water Environment, 32(1), 52-59.

Skuja, H. (1956). Taxonomische und biologische studien üder das phytoplankton schwedischer Binnengewässer. Nova acta Regiae Societatis Scientiarum Upsaliensis, Serie, 16(3), 1-104.

Smith G.M. 1950. The fresh-water algae of the United States, Mcgraw-Hill Book Company, Inc., 719pp.

Takano, K., \& Hino, S. (2009). Phylogenic analysis of Aphanizomenon flos-aquae distributed in Japan on partial sequence of rbcLX. Japanese Journal of Limnology, 69(3), 247-253.

Üveges, V., Tapolczai, K., Krienitz, L., \& Padisák, J. (2012). Photosynthtic characteristics and physiological plasticity of an Aphanizomenon flos-aquae (Canobacteria, Nostocaceae) winter bloom in a deep oligo-mesotrophic lake(Lake Stechlin, Germanay). Hydrobiologia, 698, 263-272.

Watanabe, M., (1985). Phytoplankton studies of Lake Kasumigaura. (2). On some rare or interesting algae. Bulletin National Science Museum Tokyo, Series, B17(4), 137-142.
Wu, Z. X., Shi, J. Q., Lin, S., \& Li, R. H. (2010). Unraveling molecular diversity and phylogeny of Aphanizomenon (Nostocales, Cyanobacteria) strains isolated from China. Journal of Phycology, 46(5), 1048-1058.

Yamamoto, Y. (2009). Environmental factors that determine the occurrence and seasonal dynamics of Aphanizomenon flos-aquae. Journal of Limnology, 68(1), 122-132.

Yamamoto, Y., \& Nakahara, H. (2006). Importance of interspecific competition in the abundance of Aphanizomenon flos-aquae (Cyanophyceae). Limnology, 7, 163-170.

Yu, J. J., Lee, H. J., Lee, K. L., Lyu, H. S., Hwang, J. H., Shin, R. Y., \& Chen, S. U. (2014). Relations between distribution of the dominant phytoplankton species and water temperature in the Nakdong River, Korea. Korean Journal of Ecology and Environment, 47(4), 247-257.

Zapomĕlová, E., Skácelová, O., Pumann, P., Kopp, R., \& Janeček, E. (2012). Biogeographically interesting planktonic Nostocales (Cyanobacteria) in the Czech Republic and their polyphasic evaluation resulting in taxonomic revisions of Anabaena bergii Ostenfeld 1908 (Chrysosporum gen. nov.) and A. tenericaulis Nygaard 1949 (Dolochospermum tenericaule comb. nova). Hydrobiologia, 698(1), 353-365.

Zhang, D. L., Liu, S. Y., Zhang, J., Hu, C. X., Li, D. H., \& Liu, Y. D. (2015). Antioxidative responses in Zebrafish Liver exposed to sublethal doses Aphanizomenon flosaquae DC-1 aphatoxins. Ecotoxicology and Environmental Safety, 113, 425-432.

\section{Submit your next manuscript to BioMed Central and we will help you at every step:}

- We accept pre-submission inquiries

- Our selector tool helps you to find the most relevant journal

- We provide round the clock customer support

- Convenient online submission

- Thorough peer review

- Inclusion in PubMed and all major indexing services

- Maximum visibility for your research

Submit your manuscript at www.biomedcentral.com/submit 